\title{
Investigation of Arctic ozone depletion sampled over midlatitudes during the Egrett campaign of spring/summer 2000
}

\author{
D. E. M. Ross ${ }^{1,{ }^{*}}$, J. A. Pyle ${ }^{1,2}$, N. R. P. Harris ${ }^{1,3}$, J. D. McIntyre ${ }^{1}$, G. A. Millard ${ }^{1}$, A. D Robinson ${ }^{1}$, and R. Busen ${ }^{4}$ \\ ${ }^{1}$ Centre for Atmospheric Sciences, Department of Chemistry, University of Cambridge, Cambridge, UK \\ ${ }^{2}$ NCAS-ACMSU, Department of Chemistry, University of Cambridge, Cambridge, UK \\ ${ }^{3}$ European Ozone Research Coordinating Unit, University of Cambridge, Cambridge, UK \\ ${ }^{4}$ Deutsches Zentrum für Luft- und Raumfahrt (DLR), Oberpfaffenhofen, Germany \\ *now at: JMP Consulting, London, UK
}

Received: 3 November 2003 - Published in Atmos. Chem. Phys. Discuss.: 12 January 2004

Revised: 23 July 2004 - Accepted: 17 August 2004 - Published: 27 August 2004

\begin{abstract}
A unique halocarbon dataset has been obtained using the Australian high altitude research aircraft, the Grob G520T Egrett, during May-June 2000 with GC instrument (DIRAC), which has been previously deployed on balloon platforms. The halocarbon data generally shows a good anticorrelation with ozone data obtained simultaneously from commercial sensors. On 5 June 2000, at $380 \mathrm{~K}$, the Egrett entered a high latitude tongue of air over the U.K. CFC-11 and $\mathrm{O}_{3}$ data obtained on the flight show evidence of this feature. The dataset has been used, in conjunction with a $3 \mathrm{D}$ chemical transport model, to infer ozone depletion encountered in the midlatitude lower stratosphere during the flight. We calculate that ozone is depleted by $20 \%$ relative to its winter value in the higher latitude airmass. A suite of ozone loss tracers in the model have been used to track ozone depletion according to location relative to the vortex and chemical cycle responsible. The model, initialised on 9 December, indicates that $50 \%$ of the total chemical ozone destruction encountered in June in the middle latitudes occurred in the $90-70^{\circ} \mathrm{N}$ equivalent latitude band and that $70 \%$ was due to halogen chemistry.
\end{abstract}

\section{Introduction}

Total ozone values at northern midlatitudes were $3 \%$ lower in 1997-2001 than they had been before 1980 (WMO, 2003). The decline was not linear: a minimum occurred in 1993 since when there has been a modest increase. This contrasts with the behaviour in the southern hemisphere, where total ozone is still decreasing, with 1997-2001 values 6\% lower than pre-1980 values. This illustrates the complexity of understanding ozone loss in the lower stratosphere as both chemical and dynamical factors are important (Fahey et al.,

Correspondence to: N. R. P. Harris

(neil.harris@ozone-sec.ch.cam.ac.uk)
1993; Solomon et al., 1996; Appenzeller et al., 2000). There are three principle mechanisms for chemically-driven ozone loss in the midlatitude lower stratosphere, see e.g. Pyle et al. (1995). The first is that air primed for ozone depletion in the low temperatures of the polar vortex is advected out of the vortex and into the sunlit midlatitudes where it causes ozone loss. Secondly, polar air, which has already experienced ozone depletion, may be advected into midlatitudes causing a dilution effect. Alternatively, midlatitude ozone loss could be due to in-situ reactions occurring wholly at midlatitudes.

There are a variety of measurements and techniques available for the study of polar ozone loss. For example, the "Match" technique uses numerous ozone soundings in high latitudes, and calculated air parcel trajectories, to infer changes in ozone within individual air parcels (Rex et al., 1997; Rex et al., 2002). Tracer measurements can be used to infer ozone loss by the evolution of correlations in ozone with long-lived gases, such as $\mathrm{N}_{2} \mathrm{O}$ or CFC-11 (Proffitt et al., 1990; Richard et al., 2001). These long-lived gases are good tracers, their mixing ratios remaining constant with dynamical motions. A change in their correlation with ozone can then be used to infer chemical destruction of ozone, although Plumb et al. (2000) noted that care must be taken to eliminate any mixing anomalies in the tracer-tracer relationships.

In addition to these measurement-based analyses of ozone loss, atmospheric models forced by meteorological and chemical observations have been used to investigate chemical ozone loss in polar regions (Chipperfield, 1999; Grooss et al., 2002). In contrast to the polar case, ozone loss in middle latitudes is generally much smaller than in polar latitudes and is much harder to detect and diagnose unambiguously. The study of midlatitude ozone loss has been limited to statistical trend analyses and model-based investigations (Hadjinicolaou et al., 1997; Logan et al., 1999; Weiss et al., 2001; Millard et al., 2003). 
The 1999/2000 Arctic winter saw the largest ever combined campaign to investigate Arctic ozone loss processes, the SOLVE-THESEO 2000 campaign (Newman et al., 2002). The polar low stratosphere was consistently cold, with more widespread temperatures below the PSC threshold than any other winter in the last 20 years and the largest ever local loss reported for the Arctic (Sinnhuber et al., 2000; Rex et al., 2002). Extensive denitrification occurred in the polar vortex (Fahey et al., 2001; Carslaw et al., 2002) and as a result, ozone losses were large during the winter and continued during the final warming in mid-March (when temperatures had risen above the PSC threshold) due to the hindered reconversion of $\mathrm{ClO}_{\mathrm{x}}$ to $\mathrm{ClONO}_{2}$ (Sinnhuber et al., 2000). The vortex itself was stable until the final warming when it broke up with one substantial remnant present until April (Waugh and Rong, 2002).

DIRAC and DESCARTES, two GC based instruments developed at the University of Cambridge, were deployed on several balloon flights within the Arctic vortex during the 1999/2000 winter to measure long-lived halocarbon species. Using changes in the $\mathrm{CFC}-11 / \mathrm{O}_{3}$ correlations inside the polar vortex, we have combined the DIRAC and DESCARTES measurements from 9 flights to estimate ozone loss of around $40 \%$ at $440-470 \mathrm{~K}$ by early March 2000 . These estimates agree well with our calculations using the SLIMCAT model (Millard, 2002) and are similar to those of Richard et al. (2001) who used measurements of $\mathrm{N}_{2} \mathrm{O}$ and $\mathrm{O}_{3}$ made from the NASA ER-2 aircraft to show an accumulated ozone loss of $53 \%$ near $450 \mathrm{~K}$ by 12 March 2000 . The DESCARTES measurements from two flights have been used in conjunction with HALOE and other balloon observations to estimate that a maximum loss of just over $60 \%$ occurred in the lower stratosphere (415-465 K) by mid-March 2000, alternatively expressed as a partial column loss of $84 \pm 13$ Dobson Units (DU) between 380 and $550 \mathrm{~K}$ in the vortex core (Müller et al., 2003). They also concluded that a substantial chemical loss was still observable in vortex remnants in late April 2000.

Several studies have investigated the impact of the large polar ozone depletion of 1999/2000 on midlatitudes. Millard et al. (2003) used ozone budgeting tracers within a 3D chemical transport model to show that cold disturbed Arctic winters gave the largest contribution to midlatitude ozone loss, with 75\% of midlatitude ozone loss in April 2000 originating from the pole. The cold, well isolated vortex of 1996/97 had a much smaller impact on midlatitude ozone. Between $40 \%$ and $70 \%$ of midlatitude ozone loss was due to reactions with halogen species. Hauchecorne et al. (2002) used a high-resolution isentropic model to show that, for winters with a cold, strong vortex such as 1999/2000, there is relatively little filamentation of the vortex to midlatitudes. Nevertheless, Godin et al. (2002) used the same model and ozonesonde data from a midlatitude site to estimate a $4 \%$ reduction of ozone between $400-500 \mathrm{~K}$ due to the transport of ozone-depleted, polar vortex air over the site during the win- ter. Marchand et al. (2003) expanded this work to show that, by April, $50 \%$ of ozone loss between $45-55^{\circ} \mathrm{N}$, at $475 \mathrm{~K}$, had occurred in the vortex, i.e. had been mixed into midlatitudes.

Piani et al. (2002) used a high resolution SLIMCAT simulation to study the transport of polar air to midlatitudes after the breakup of the vortex in 2000. They showed that most of the air contained in the polar vortex above $420 \mathrm{~K}$ had been mixed and transported to low latitudes by the end of June 2000. Below $420 \mathrm{~K}$, however, it was confined to north of $55^{\circ} \mathrm{N}$ by an upward extension of the tropospheric subtropical jet. Vortex remnants were present until the end of June. The model study of Konopka et al. (2003) also indicates that vortex remnants are still present in the lower stratosphere $(450 \mathrm{~K})$ in early June, but that they will not have remained intact and will be influenced to some extent by mixing with non-vortex air. Their estimated remnant lifetime of 5 weeks at $450 \mathrm{~K}$ is consistent with the observation of intact vortex remnants in late April (Müller et al., 2003).

This does raise the question of how far mixing will have affected the $\mathrm{O}_{3} / \mathrm{CFC}-11$ relationship measured in June and whether it can be used to deduce ozone loss. The main point is that the $\mathrm{O}_{3} / \mathrm{CFC}-11$ relationship in this winter was very close to linear (Müller et al., 2003 and discussion below), and mixing within a linear relationship cannot alter the relation only chemical loss (or production) can.

All these studies are limited to model-based investigations with some comparison to ozonesonde data, and in the case of Piani et al. (2002) data obtained within the polar vortex during SOLVE-THESEO 2000. As yet, no studies have used long-lived tracer data obtained in the middle latitudes to investigate middle latitude ozone loss and the mixing from the vortex.

This paper explores whether a unique dataset, similar to those used in the estimation of ozone loss in the polar vortex, can be used to detect ozone loss of Arctic origin in the midlatitude lower stratosphere over the UK. Long-lived halocarbon and ozone measurements of the midlatitude lower stratosphere were obtained during the Egrett Campaign, held out of Boscombe Down, UK, during May-June 2000. This campaign and particularly the flight of 5 June 2000 are discussed in Sect. 2. Brief descriptions of the measurements and the SLIMCAT 3D chemical transport model used in this study are given in Sect. 3. The analysis of the measurements and the model output is discussed in Sect. 4. First, the synoptic situation on 5 June is discussed. Modelled and measured $\mathrm{O}_{3} /$ CFC-11 relationships in January and June 2000 are compared and used to identify regions of ozone-depleted air. A suite of tracers in the model is used to investigate the origin of the ozone loss and the chemical cycles responsible for the depletion. It is interesting to see what the ozone loss over the U.K. might have been if the Egrett campaign been in late Spring, and, in Sect. 5, we describe a model study of a hypothetical flight on 5 April along the same flight track. Some conclusions are drawn in Sect. 6. 

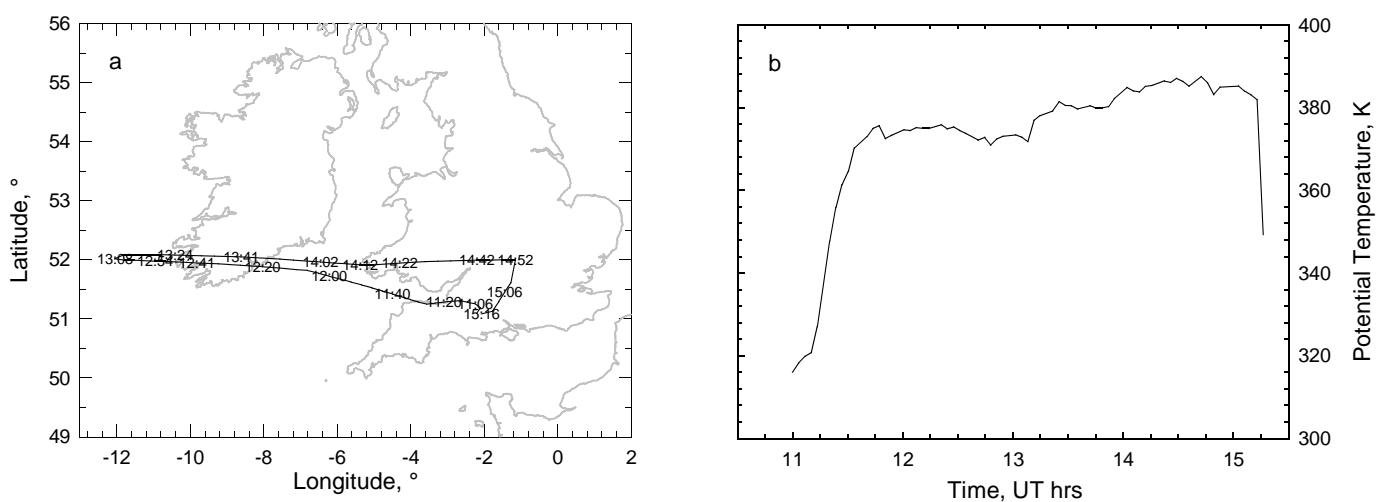

Fig. 1. (a) Egrett flight track on 5 June 2000, labelled with time stamps of DIRAC measurements during flight (UT).The flight can be divided into two legs, westwards and eastwards. (b) Altitude profile of the Egrett flight on 5 June 2000 plotted against time. The aircraft ascended to $390 \mathrm{~K}$ at $1300 \mathrm{~h}$. From (a), the aircraft was about to begin the eastwards flight leg.

\section{The Egrett campaign and 5 June flight}

The Egrett Campaign consisted of 17 flights of the Airborne Research Australia Grob G520T Egrett aircraft during 6 weeks from 1 May 2000 to 6 June 2000. The Egrett is capable of carrying a payload of $750 \mathrm{~kg}$ to a maximum altitude of $15 \mathrm{~km}$. Onboard the aircraft throughout the campaign were a variety of instruments measuring turbulence, methane, ozone, water vapour and halocarbons. The principal aims were to study the effects of gravity waves, mixing and turbulence on the UTLS. An additional aim was to investigate ozone loss mechanisms in the very low stratosphere. The flight tracks were designed to capture interesting features of the atmosphere on any particular day and, of 17 flights, 7 were designed for the study of mixing, ozone loss and larger scale waves and filamentation.

Figure 1 shows the flight track and altitude profile of the aircraft during the 5 June flight, one of the flights carried out to investigate the larger scale issues of mixing and ozone loss. The aircraft ascended to a cruising altitude of $370 \mathrm{~K}$ and flew directly westwards over Ireland. It then ascended to a second cruise altitude of $385 \mathrm{~K}$ as it turned 180 degrees and flew directly eastwards back to Boscombe Down. This particular flight was the subject of a study by Bradshaw et al. (2002). They used ECMWF PV and wind fields to evaluate the synoptic situation on that day and identified a large intrusion of subtropical tropospheric air, as characterised by Peters and Waugh (1996), off the west coast of Europe. This intrusion was caused by a large-scale Rossby wave breaking along the edge of the stratosphere. In addition to the subtropical intrusion, a large tongue of stratospheric air extended over France and Spain.

In their study, Bradshaw et al. (2002) used high-resolution measurements of methane and ozone on 5 June 2000 to observe fine scale tracer filamentation. They proposed the fine scale structure in the dataset was caused by small-scale Rossby waves breaking on the flank of the larger wave feature described above.
Here we use data from two instruments, the University of Cambridge DIRAC in situ gas chromatograph (Robinson et al., 2000) measuring CFC-11 $\left(\mathrm{CCl}_{3} \mathrm{~F}\right)$ and other halocarbons and a UV photometer measuring ozone, also used by Bradshaw et al. (2002). These data are of much lower spatial and temporal resolution than the measurements used in the study by Bradshaw et al. (2002). However, the edge of the large subtropical intrusion and the tongue of stratospheric air are evident in this dataset and in the model to be described below. Together these are used to investigate the impact of Arctic ozone loss on the middle latitudes on this day.

\section{Instruments and model}

DIRAC is a lightweight ( $21 \mathrm{~kg}$ ) gas chromatograph designed for deployment on balloon and aircraft platforms. The instrument is described in detail in Robinson et al. (2000). DIRAC had previously been deployed on 5 balloon flights during SOLVE-THESEO 2000 and was operated successfully on 16 flights of the Egrett. For aircraft operation, the instrument took measurements at regular time intervals, typically $2 \mathrm{~min}$. On this aircraft platform this corresponds to a horizontal resolution of approximately $3 \mathrm{~km}$.

The DIRAC sampling system consists of a sample trap containing Carboxen adsorbent, which is selective to halocarbons and so concentrates the atmospheric sample before analysis. A pump and flowmeter allow for a known volume of air to be concentrated on the trap during sampling. After sampling, the trap is heated and the sample injected into a separation column and electron capture detector. The resulting chromatograms are stored and downloaded after the flight. A range of halocarbons can be detected, and the system is optimized for CFC-11 with an estimated accuracy of $2.9 \%$ related to the uncertainty of the standard gas used for calibrations. During the campaign, DIRAC was configured so that a sample was taken from the onboard NOAA-CMDL calibration gas after a block of 5 atmospheric samples. A 


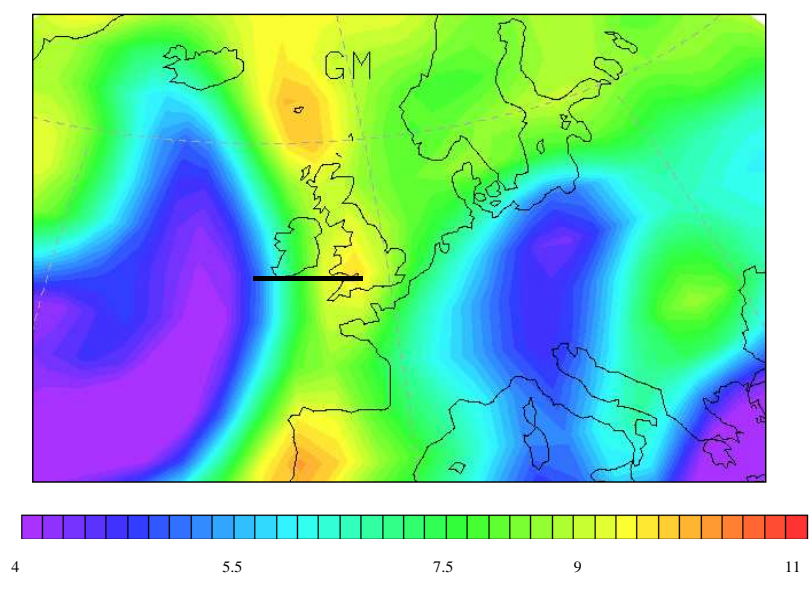

Fig. 2. ECMWF potential vorticity field at $380 \mathrm{~K}$ and $2.5^{\circ} \times 2.5^{\circ}$ resolution on 5 June 2000. The flight track is superimposed to give an idea of the airmasses encountered during the flight.

sensitivity study has been carried out in the laboratory using the calibration gas to obtain a plot of mass of CFC-11 (pg) versus peak area. A quadratic fit applied to this plot is used to determine the mass of CFC-11 for each calibration chromatogram obtained during the flights. As the volume of each sample is measured, a volume mixing ratio can be obtained. For the calibration samples, these are compared to the known mixing ratio of the calibration gas and a sensitivity correction factor calculated. During the campaign, with a calibration sample obtained every 5 atmospheric samples, a linear interpolation between the calibration before and after the block of atmospheric samples allows for a sensitivity correction factor to be applied to all samples. In-flight precision can be determined from the standard deviation of the linear fit of mass of CFC-11 (pg) versus peak area for all the calibration samples obtained during all flights. The average precision was $1.7 \%$.

The ozone sensor used was a model TE-49C ultraviolet absorption spectrometer, manufactured by Thermo Environment Instruments Ltd., Franklin, Massachusetts and provided by the Deutches Zentrum für Luft- und Raumfahrt (DLR). It produced slow ozone measurements with a response time of 10-20 s. For high resolution studies, this dataset was modulated with a high frequency signal from a fast, but less accurate, chemiluminescence sensor, also provided by DLR and capable of a response time of $200 \mathrm{~ms}$. Here, for comparison with DIRAC, a running average over $60 \mathrm{~s}$ of the high resolution dataset was calculated. $60 \mathrm{~s}$ is the time for DIRAC to sample the desired volume in the stratosphere. The measurement at the time corresponding to the DIRAC sample midpoint was then picked out from the 60s-averaged ozone dataset as the corresponding ozone measurement.

Modeling studies of all the Egrett flights have been carried out using the SLIMCAT 3D chemical transport model (Chipperfield, 1999; Millard et al., 2003). SLIMCAT is an offline model driven by daily ECMWF winds and tempera- tures on 18 isentropic levels from $335-2700 \mathrm{~K}$, with a horizontal resolution of $3.75^{\circ} \times 3.75^{\circ}$. It uses the MIDRAD radiation scheme (Shine, 1987) to calculate cross-isentropic flow and the Prather second order moments scheme (Prather, 1986) to calculate tracer advection. The model contains a detailed stratospheric chemistry scheme with 49 chemical species and includes an equilibrium treatment of heterogeneous processes occurring on solid nitric acid trihydrate particles, ice particles and liquid sulfate aerosols. All runs presented here are initialized on the 9 December 1999 and carried forward to June 2000 and output is taken at $15 \mathrm{~min}$ intervals. Comparisons of the ozone mixing ratios in SLIMCAT with measurements show good agreement in the 1999/2000 winter (Sinnhuber et al., 2000).

In addition to the chemistry scheme, the model contains a suite of chemical and geographical ozone loss tracers, described in detail by Lee et al. (2001) and Millard et al. (2003). The chemical tracers track ozone depletion according to the chemical cycle responsible, wherever it may have occurred, and follow destruction due to $\mathrm{Cl}_{2} \mathrm{O}_{2}+h v, \mathrm{ClO}+\mathrm{O}, \mathrm{NO}_{2}+\mathrm{O}$, $\mathrm{HO}_{2}+\mathrm{O}_{3}, \mathrm{ClO}+\mathrm{BrO}, \mathrm{HO}_{2}+\mathrm{ClO}, \mathrm{HO}_{2}+\mathrm{BrO}$ and production by $\mathrm{O}_{2}+h v$. The geographical tracers track ozone destruction, as a result of all cycles, by its location relative to the vortex. For that purpose, the Northern Hemisphere is divided into $10^{\circ}$ equivalent latitude bands over all levels. Ozone depletion within each latitude band is then calculated from the sum of the ozone destruction terms in the chemistry scheme. Both sets of tracers are cumulative from initialisation. These tracers have been used previously to indicate, for example, how much midlatitude ozone loss occurred in the vortex latitudes or due to halogen chemistry (Millard et al., 2003). They are used for similar purposes here to track the origin of ozone destruction encountered during the campaign.

\section{A case study of midlatitude ozone loss}

\subsection{Synoptic situation on 5 June 2000}

Figure 2 shows an isentropic map from ECMWF of potential vorticity (PV) on the $380 \mathrm{~K}$ level at midday on the 5 June 2000, with a schematic of the Egrett flight track from Fig. 1 superimposed. The large subtropical intrusion and the tongue of higher latitude stratospheric air described in section 2 can be seen. Picturing the Egrett flight on that day (see Figs. 1 and 2), it would appear that, flying to the west, the aircraft ascended in and then exited the tongue of high PV air, originating from the stratosphere at higher latitudes. Off the west coast of Ireland, it then entered a lower PV feature, originating from the subtropical tropopause, where it ascended once more before turning and re-entering the high PV tongue at a slightly higher altitude. This is supported by the data in Fig. 3, which show ozone and CFC-11 against flight time from the model and the observations, as well as equivalent latitude calculated from the PV field in the model. 
The data show a rise in CFC-11 (drop in ozone) as the aircraft enters the lower latitude air. There is good agreement between model and measurement in high latitude air resulting from the relatively strong influence of higher altitude air as a result of descent through the polar winter. The poorer agreement in mid and low latitude air results from a stronger influence of the bottom boundary. The focus of this study is the diagnosis of the ozone loss occurring in the high latitude air using measured ozone-tracer correlations and so this should not affect our results. The model also does not pick out the steepness of the gradients seen in the data, but this is to be expected at the $\mathrm{T} 31,3.75^{\circ} \times 3.75^{\circ}$ horizontal resolution considered.

Also shown in Fig. 3 is a modeled passive ozone tracer, which has simply been advected since initialization in December 1999 and has not been subjected to chemical production or destruction reactions in the chemistry scheme. Just looking at the ozone dataset along the flight, it is not obvious whether we have sampled ozone-depleted air. In contrast, the difference between the modeled ozone (in good agreement with the data) and the modeled passive ozone, which has undergone no chemistry, indicates that, in the model, there has been some chemical destruction of the ozone encountered on the flight path, especially in the higher equivalent latitude air. The next step is to investigate the tracer-tracer correlations, and see if they can be used to identify ozone loss.

\subsection{Detecting midlatitude ozone loss}

As discussed earlier, ozone loss is often inferred from a change in correlation between ozone and an inert tracer, such as CFC-11 or $\mathrm{N}_{2} \mathrm{O}$ (Proffitt et al., 1990). For example, this technique has been used to quantify loss in the Arctic vortex of 2000, which was well mixed and isolated between January and early-March. Ozone loss can be detected by taking the difference in $\mathrm{O}_{3} / \mathrm{CFC}-11$ correlation before (e.g. a reference, undepleted correlation in January) and after the return of sunlight. Peak ozone losses of 53\% have been calculated for the Arctic lower stratosphere using a tracer dataset (Richard et al., 2001) who provided ozone loss rate estimates from $390-450 \mathrm{~K}$ between 20 January and 12 March 2000. For the Egrett dataset to be used to infer ozone loss in middle latitudes from a change in $\mathrm{CFC}-11 / \mathrm{O}_{3}$ correlation, we clearly would also need a reference, a measurement of the correlation before loss occurred. No such measurement was obtained during the Egrett campaign, as time scales for ozone loss at middle latitudes are long and the campaign was short. However, there were measurements of CFC-11 and ozone taken in the Arctic vortex earlier in the year during the winter campaign, before any loss occurred. Also, we have a model with a passive ozone tracer that has undergone no chemistry and has simply been advected since initialization. We show next that the model results support the use of the measured CFC- $11 / \mathrm{O}_{3}$ correlation in January as a baseline comparison with the Egrett dataset.
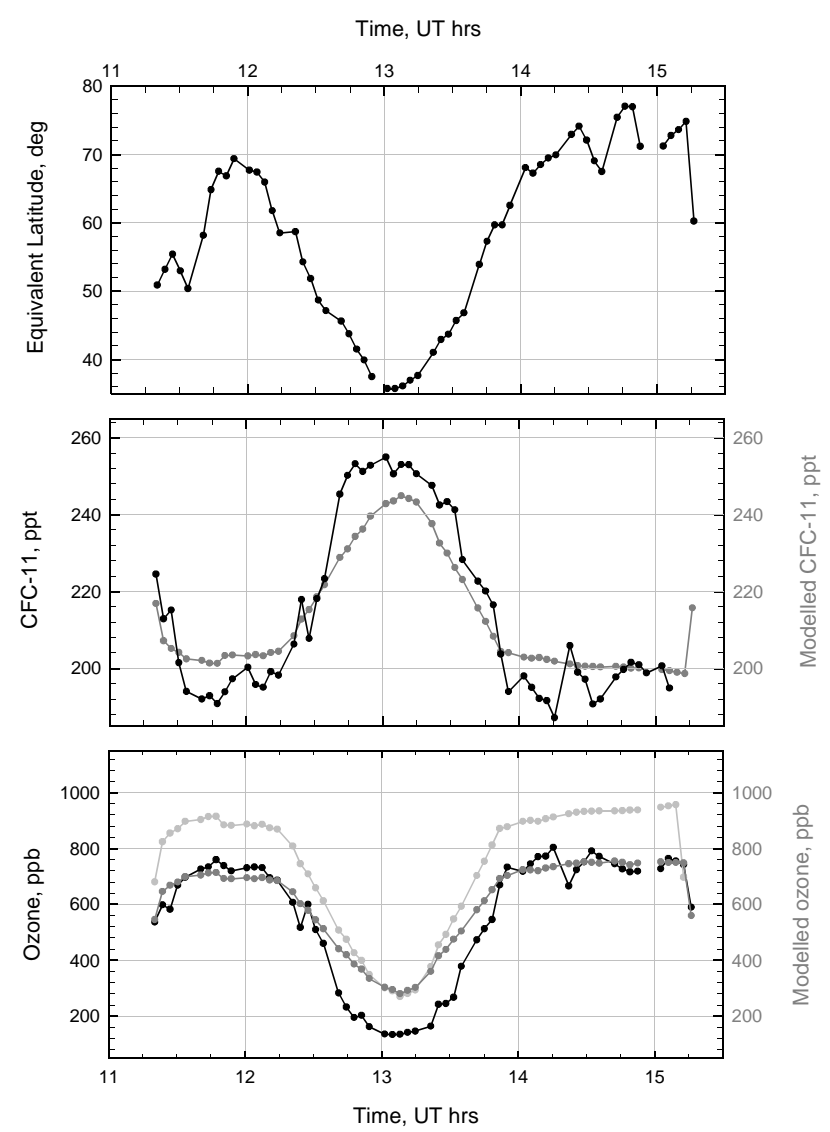

Fig. 3. (a) Modeled equivalent latitude, determined by the potential vorticity field. (b) Modeled CFC-11 (grey) and measured CFC-11 (black) from DIRAC. (c) Modeled passive ozone (light grey), chemical ozone (grey) and measured ozone (black) from the commercial ozone sensor. Model data have been interpolated onto the time and location of the Egrett flight on 5th June 2000.

Figure 4a shows model correlations of CFC-11 against passive ozone for the time and location of three flights: (1) a flight of the NASA-ER2 aircraft on 14 January 2000 made within the Arctic vortex during SOLVE-THESEO 2000, (2) a profile from a DIRAC balloon flight on 19 January 2000 also made within the Arctic vortex during SOLVE-THESEO 2000 and (3) the Egrett flight on 5 June 2000. In addition to the model correlations, CFC-11 and ozone correlations from the data obtained on the two Arctic vortex flights in January are also shown.

There are three points to note from this figure. First, the passive $\mathrm{O}_{3} /$ CFC- 11 model correlation in January matches the January measurements well and so it is a good representation of the correlation before significant ozone loss. Second, the $\mathrm{O}_{3} / \mathrm{CFC}-11$ is straight, so any deviations results from chemical processes. Third, the passive $\mathrm{O}_{3} / \mathrm{CFC}-11$ correlation in the Arctic during January is the same as the passive $\mathrm{O}_{3} / \mathrm{CFC}$ 11 correlation over the UK in June, and so may still be considered an appropriate reference for the correlation before 

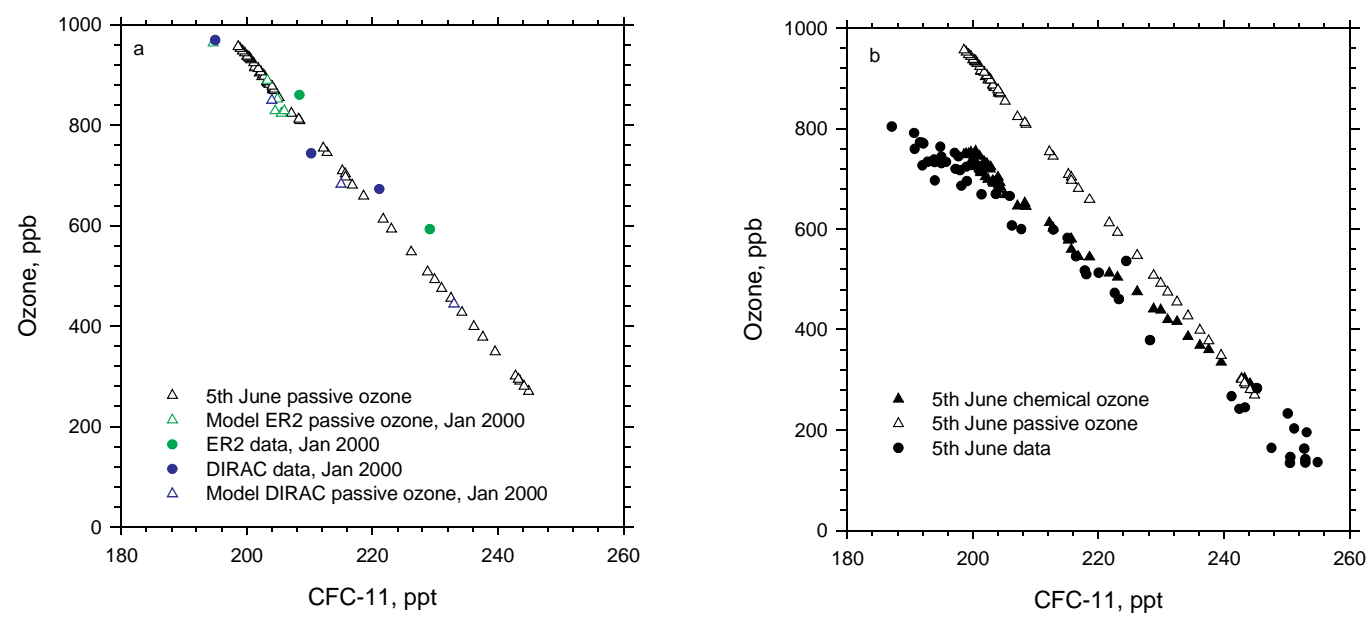

Fig. 4. (a) Modelled passive ozone/CFC-11 correlation (triangles) for an ER-2 flight on 14/01/2000 (Richard et al., 2001), a DIRAC balloon flight on 19/01/2000, both in the Arctic vortex, and the Egrett flight on 05/06/2000 in midlatitudes. The measurements from the ER-2 aircraft and DIRAC balloon flights in the vortex are also shown. (b) Modelled passive and chemical ozone/CFC-11 correlations, interpolated onto the flight track of the Egrett on 5 June 2000, and the data correlation obtained on the flight from DIRAC and a commercial ozone sensor. Plot shows ozone loss of $\sim 200 \mathrm{ppbv}$ at the $200 \mathrm{pptv}$ CFC-11 level ( $380 \mathrm{~K})$.

ozone loss has occurred. So, although we do not have a measured reference correlation from the Egrett campaign, the comparison of winter time data and model correlations supports the use of the model passive correlation as a reference.

Figure $4 \mathrm{~b}$ shows the modeled correlations of CFC-11 against passive and chemical ozone for the time and location of the Egrett flight on 5 June 2000. Also shown here is the data correlation obtained by DIRAC and the ozone sensor during that flight. The modeled chemical $\mathrm{O}_{3} / \mathrm{CFC}$ 11 correlation is in good agreement with the measurements in the higher latitude air and a comparison with the modeled passive $\mathrm{O}_{3} / \mathrm{CFC}-11$ correlation (the correlation before any chemical ozone loss had occurred) indicates that ozone loss was indeed encountered on the flight track of the 5 June 2000. The amount of ozone loss inferred is approximately 200 ppbv ozone loss (i.e. a $20 \%$ decline from the expected midwinter undepleted ozone) at the 200 pptv CFC-11 level, corresponding to an altitude of $380 \mathrm{~K}$ on 5 June 2000 . Note in passing that the scatter about the reference profiles (Fig. 4a) is much smaller than the calculated ozone loss (Fig. 4b), further validating the use of the model reference.

\subsection{Attributing the mechanisms behind ozone loss}

Figure 5 shows the contributions to the model ozone loss found in the midlatitude partial column between $342-510 \mathrm{~K}$ and between model equivalent latitudes contours $30-60^{\circ} \mathrm{N}$, as in Millard et al. (2003). The accumulated partial column loss is just over 10 Dobson Units. Of this, about 3 D.U. has taken place between in the reduced partial column between 240 and $400 \mathrm{~K}$. Figure 5a breaks down the ozone loss in the partial midlatitude column according to the region in which the ozone loss occurred. Figure $5 \mathrm{~b}$ shows the contributions of individual cycles to the ozone loss. Ozone depletion occurring in polar regions has a marked influence on the modelled ozone loss at midlatitudes after the final warming and breakup of the vortex on around day 80 (Fig. 5a). By 5 June (day 157), depletion that has occurred in the polar region (90$70^{\circ} \mathrm{N}$ and $70-60^{\circ} \mathrm{N}$ bands) accounts for $\sim 45 \%$ of the total ozone depletion in the midlatitude partial column. Similarly, until day 80 there is little contribution to ozone loss from the $\mathrm{Cl}_{2} \mathrm{O}_{2}$ cycle (Fig. 5b) as the loss from this cycle would be contained within the polar vortex. This cycle is only expected to be active in the polar vortex due its the strong negative temperature dependence and quadratic dependency on the $\mathrm{ClO}$ concentration. Therefore it can be used as a marker for polar ozone depletion. After day 80, ozone depletion due to the $\mathrm{Cl}_{2} \mathrm{O}_{2}$ cycle is present in the midlatitude partial column.

When these tracers are output along the flight track it can be seen that, as expected, the higher PV (latitude) air encountered at the beginning and end of the flight shows the greatest ozone depletion (Fig. 6). Along the flight track, a substantial portion $(\sim 50 \%)$ of the chemical ozone depletion has come from high latitudes, $90-70^{\circ} \mathrm{N}$, which would have included the polar vortex earlier in the winter (Fig. 6a). However, some of the ozone loss in the high PV air occurred within the midlatitude bands as well, with $\sim 20 \%$ of the total chemical loss coming from the region between $60-30^{\circ} \mathrm{N}$ equivalent latitude. In the polar vortex, the $\mathrm{Cl}_{2} \mathrm{O}_{2}$ and $\mathrm{ClO}-\mathrm{BrO}$ cycles are active in a roughly $1: 1$ ratio and this can be seen in Fig. $6 \mathrm{~b}$ (ClO-BrO is slightly more dominant as it is active in midlatitudes, see also Millard et al. (2003)). Both cycles 

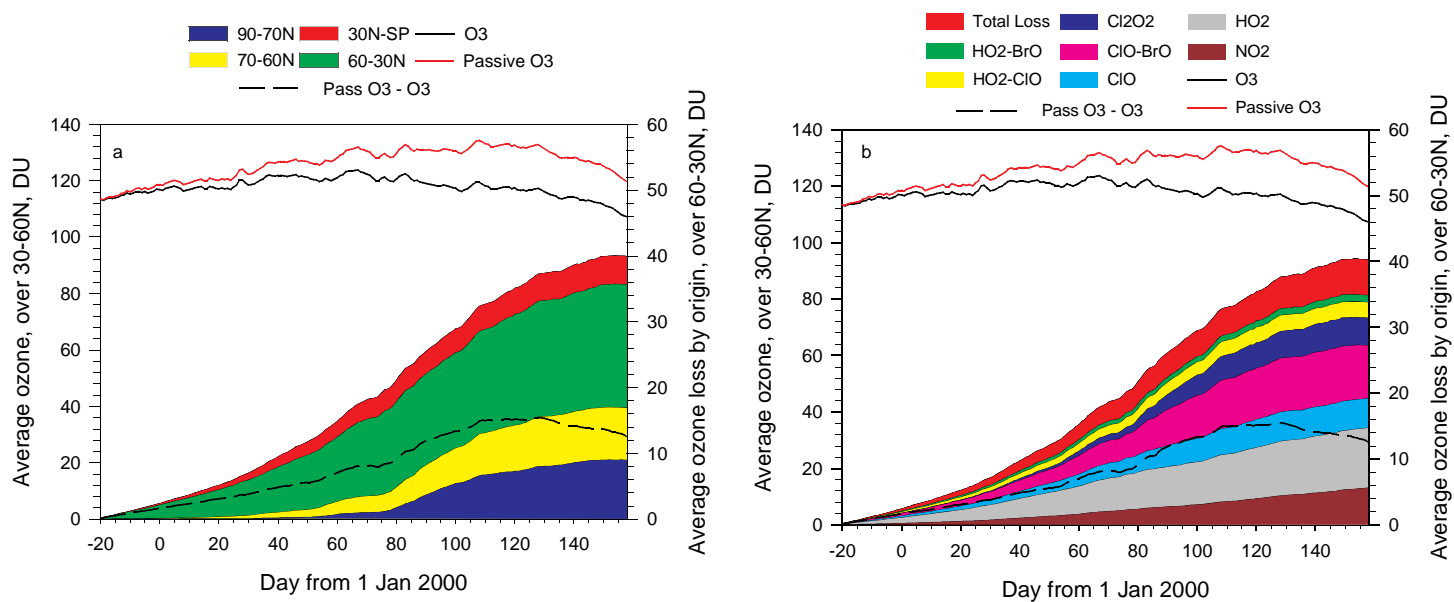

Fig. 5. Average ozone loss (DU) within equivalent latitude band $60-30^{\circ} \mathrm{N}$ for the partial column $342-510 \mathrm{~K}$, plotted in colour according to (a) the origin of the ozone loss and (b) the chemical cycle responsible. Ozone loss is cumulative from 9 December 1999. Also shown is the model passive and chemical ozone partial column values. The difference is equivalent to net ozone loss $\left(\mathrm{Pass}_{3}-\mathrm{O}_{3}\right)$.
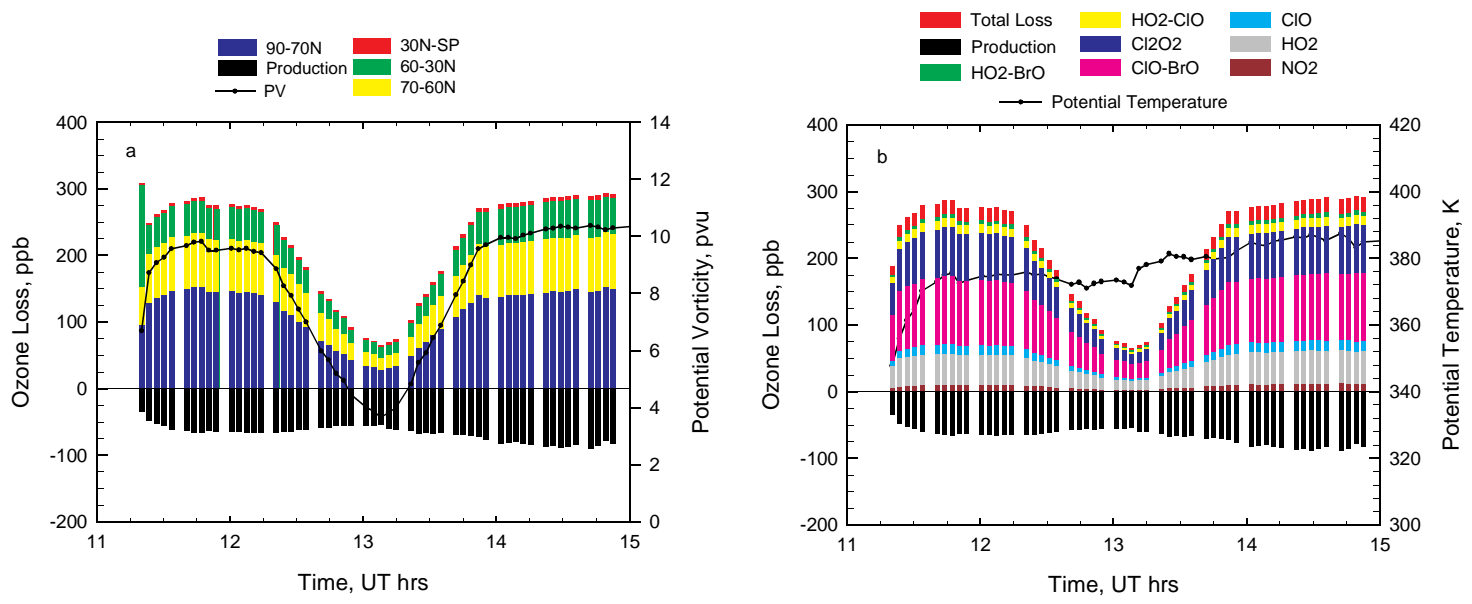

Fig. 6. Total chemical ozone loss (and production) encountered along the flight track of 5 June, plotted according to (a) location relative to the vortex and (b) chemical cycle responsible.

combined account for approximately $50 \%$ of the chemical ozone destruction encountered along the flight track.

It should also be noted that, although the higher latitude airmass sampled at the beginning and end of the flight has greater net ozone loss, the chemical loss within the lower latitude airmass also has a 50\% contribution from high latitudes. Production by $\mathrm{O}_{2}$ photolysis balances the loss such that there is negligible net ozone loss in this airmass, but evidently the model appears to have efficiently mixed the polar vortex into the midlatitude domain by 5 June 2000 .

A novelty of the cycle tracers is that ozone loss due to halogen chemistry alone can be calculated, by simply summing the ozone destruction occurring due to all cycles containing halogens. Halogens have very few natural sources in the stratosphere, so this is a good approximation of the impact of manmade pollutants containing halogens. For the flight on 5 June 2000, approximately $70 \%$ of the ozone destruction encountered was caused by halogen chemistry.

In order to investigate whether the analysis of the 5 June flight shown in Fig. 6 is typical of the midlatitude domain or unique to this local event, the zonal mean values at $52^{\circ} \mathrm{N}$ and $380 \mathrm{~K}$ have been evaluated. As can be seen from Fig. 7, the zonal mean values are indeed consistent with those for the 5 June flight track. $50 \%$ of the ozone destruction at $52^{\circ} \mathrm{N}$ has come from high latitudes $\left(90-70^{\circ} \mathrm{N}\right)$, and $70 \%$ of the ozone destruction was due to halogen chemistry.

Figure 7 shows an interesting time development on the $380 \mathrm{~K}$ surface, which can be contrasted with the behaviour integrated through the lower stratosphere $(342-510 \mathrm{~K})$ shown in Fig. 5. In Fig. 7, the ozone loss in the lowermost 


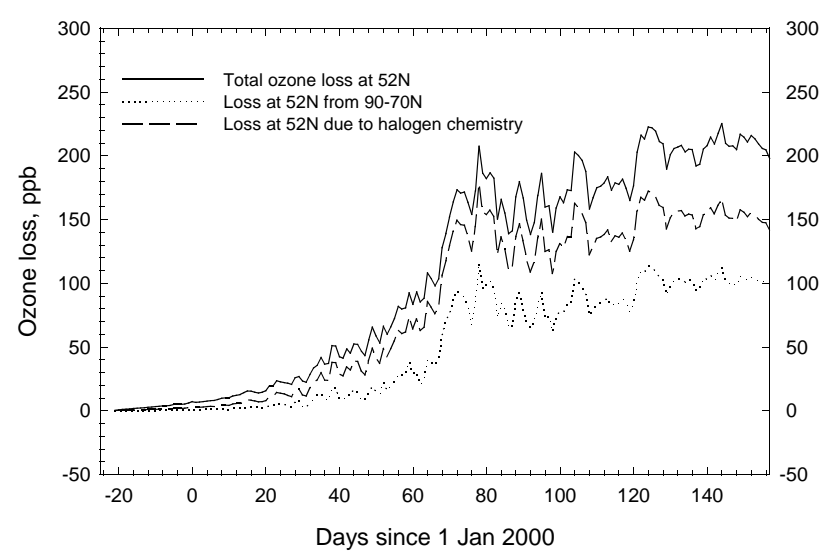

Fig. 7. Zonal mean time series of ozone loss in the midlatitude lower stratosphere $\left(52^{\circ} \mathrm{N}, 380 \mathrm{~K}\right)$. Total ozone loss is correlated to ozone occurring at high latitudes $\left(90-70^{\circ} \mathrm{N}\right)$ and loss due to halogens. High latitude ozone loss and loss due to halogens increase in midlatitudes throughout the winter, indicative of a subvortex region with vigorous horizontal transport between the vortex and midlatitudes in the lower stratosphere.

stratosphere increases steadily from January onwards up to day 80 and arises mainly from halogen cycles, mostly from the higher polar latitudes $\left(90-70^{\circ} \mathrm{N}\right)$. (Day 80 is when the vortex warmed and started to breakdown, and when the low temperature (dimer cycle) polar loss would have stopped). In contrast, the ozone loss integrated through the lower stratosphere (Fig. 5) arising from polar latitudes grows only slowly up to day 80 . So, the middle latitude loss before day 80 confined to the lowermost stratosphere is mainly of polar origin and occurs through gradual, efficient mixing in the subvortex region (Haynes and Shuckburgh, 2000). It seems that during this period the polar subvortex is supplied with ozonedepleted air from above.

After about day 80 the transport characteristics change. There is now a much more efficient mixing at higher altitudes in the lower stratosphere (note the rapid increase in Fig. 5) while at the same time the ozone loss rate in the lowermost stratosphere ( $380 \mathrm{~K}$, see Fig. 7) decreases. So, if we think of a model for transport of ozone-depleted air in the middle latitudes we can identify two regions. First, before the breakdown of the vortex (accompanied by a rise in temperature and cessation of polar ozone loss), ozone depleted air is transported to middle latitudes via descent in the vortex and then efficient mixing in the subvortex region (below $\sim 400 \mathrm{~K})$. After the vortex breakdown, the model results indicate that this route is short-circuited and that there is instead very efficient mixing at somewhat higher altitudes. About $50 \%$ of the modeled ozone loss at $380 \mathrm{~K}$ occurred at 70 $90^{\circ} \mathrm{N}(\mathrm{EL})$ and a further $25 \%$ occurred as a result of halogen loss processes. Some of this would have been a continuation of the high latitude loss which occurred when activated airmasses were transported to mid-latitudes. However further

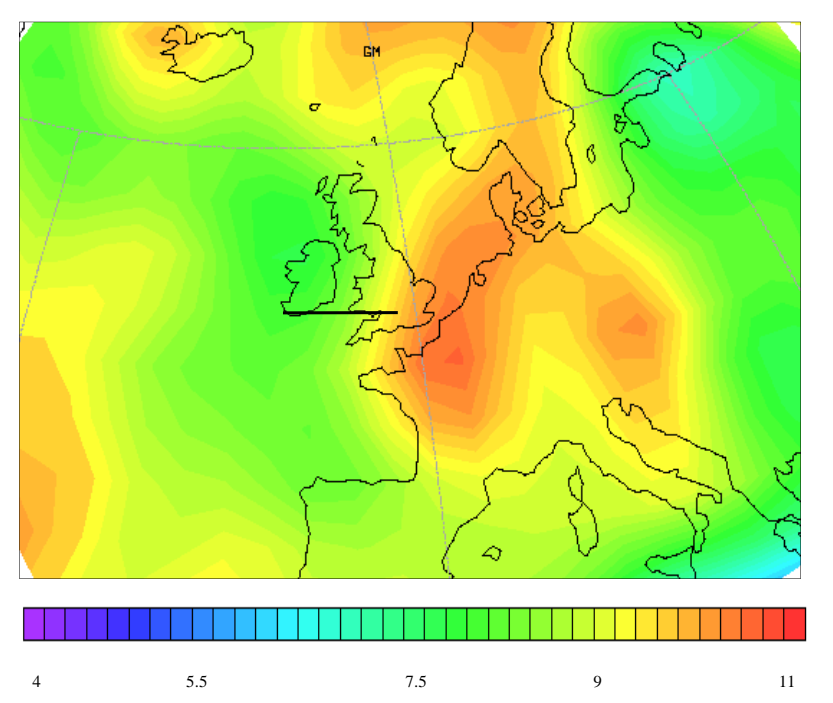

Fig. 8. ECMWF potential vorticity field at $380 \mathrm{~K}$ and $2.5^{\circ} \times 2.5^{\circ}$ resolution on 5 April 2000 at $1200 \mathrm{~h}$. The flight track of 5 June 2000 is superimposed to give an idea of the airmasses that would have been encountered during this hypothetical flight.

chemical ozone loss must also have taken place in the vortex remnants after the main vortex breakdown, consistent with the model results of Konopka et al. (2003) at $450 \mathrm{~K}$.

\section{Hypothetical flight of 5 April 2000}

The ozone loss encountered on 5 June 2000 is modest in comparison to the large ozone loss measured in the 1999/2000 polar vortex (e.g. Rex et al., 2002), and it is interesting to see what the ozone loss over the UK might have been if the Egrett campaign had been in late Spring. In order to investigate this, a model experiment has been conducted in which we assume the Egrett flew exactly the same flight path as 5 June 2000, but 2 months earlier. At this time, the vortex had split but a clear remnant remained (Manney and Sabutis, 2000). The PV field at $380 \mathrm{~K}$ for 5 April 2000 shows a clear tongue of very high PV air over the UK (Fig. 8). As on 5 June, the aircraft would have ascended in this tongue and flown westwards into a region of lower PV before ascending to a slightly higher altitude and re-entering the high $\mathrm{PV}$ tongue.

The same ozone loss tracers from SLIMCAT on the flight track for 5 April 2000 (Fig. 9) show a much greater ozone loss in the higher PV airmass than the lower PV airmass. About $60 \%$ of the ozone destruction on the 5 April flight track has come from the $90-70^{\circ} \mathrm{N}$ equivalent latitude band (Fig. 9a), and so compared to the June flight, there is a smaller contribution from ozone loss occurring between 60 $30^{\circ} \mathrm{N}$, i.e. within the midlatitude domain. In April, midlatitude lower stratosphere ozone loss is dominated by polar 

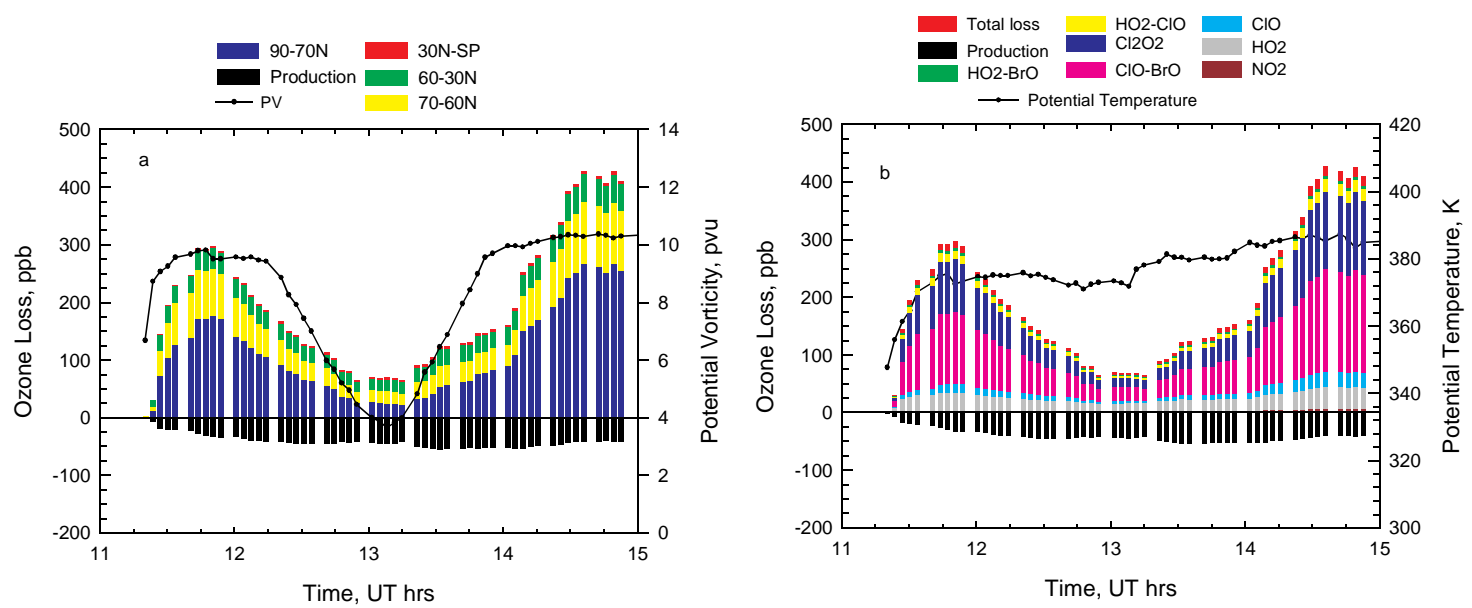

Fig. 9. Total chemical ozone loss (and production) encountered along the hypothetical flight of 5 April 2000, plotted according to (a) location relative to the vortex and (b) chemical cycle responsible. The flight track was identical to the flight of 5th June 2000.

depletion but, by June, the slower ozone loss occurring insitu (between $60-30^{\circ} \mathrm{N}$ ) is also important. The cycle tracers confirm this (Fig. 9b) with a high proportion of the chemical destruction in the high latitude airmass due to the dimer cycle and $\mathrm{ClO}-\mathrm{BrO} .85 \%$ of the ozone depletion in the high latitude airmass is due to halogen chemistry, and there is a much more polar signature to the ozone destruction in the higher PV airmass on 5 April than on 5 June. It follows that there has been less mixing between the vortex and midlatitudes by 5 April 2000.

By 5 June 2000, the lower latitude air encountered on the flight track showed $\sim 50 \%$ contribution to ozone destruction from high latitudes (although production balanced this effect). For 5 April, the lower latitude air has only $\sim 35 \%$ contribution from high latitudes. In addition, $\sim 20 \%$ of the ozone destruction in the lower latitude airmass is due to the midlatitude $\mathrm{HO}_{2}$ cycle but this cycle contributes much less $(\sim 5 \%)$ in the higher latitude airmass which is dominated by polar chemistry.

\section{Conclusions}

A unique dataset was gathered during the Egrett aircraft campaign held in early summer 2000 out of the UK. The Egrett high altitude aircraft carried out 17 flights in the middle latitude upper-troposphere and lower stratosphere with a detailed instrument payload. The DIRAC instrument was successfully deployed on 16 flights, the first deployment of DIRAC on an aircraft platform. Reliable halocarbon data were retrieved showing a good anti-correlation with ozone data obtained simultaneously from a commercial sensor. CFC-11, ozone and a passive ozone tracer were taken from the SLIMCAT CTM at the time and location of the Egrett flight track of 5 June 2000. The DIRAC CFC-11 data, ozone data and model output are in good agreement, particularly for the higher latitude air.

In order to use the data and the tracer-tracer method to infer ozone depletion, a reference of the $\mathrm{O}_{3} / \mathrm{CFC}-11$ correlation before any chemical ozone loss occurred was obtained. Using this, we estimate that $20 \%$ of the ozone had been depleted (relative to the passive reference ozone field) in the high PV airmass encountered on the flight track. Using a suite of ozone loss tracers that track depletion according to location and the chemical cycle responsible, we show that $50 \%$ of the total chemical loss encountered in the midlatitude lowermost stratosphere was of high latitude origin $\left(90-70^{\circ} \mathrm{N}\right.$ equivalent latitude). $70 \%$ of the total chemical loss was due to halogen chemistry. A time series of the contributions to ozone depletion at $52^{\circ} \mathrm{N}$ and $380 \mathrm{~K}$ showed that the middle latitude lower stratosphere was exposed to ozone loss occurring in the polar vortex throughout the winter and not just after the break up of the vortex. This arises from transport in a subvortex region below the vortex edge barrier. After the breakup of the vortex there is effective mixing of ozonedepleted air at higher altitudes.

The model results for a hypothetical flight 2 months earlier show a polar remnant would have been sampled over the UK. In April, this airmass retained a much more polar signature with $30 \%$ ozone depleted air encountered and $60 \%$ of the total chemical ozone loss occurring in high latitudes (90$70^{\circ} \mathrm{N}$ ). The contribution to ozone loss from the dimer cycle and other halogen cycles were much higher at $85 \%$. Again, lower latitude air was also sampled along the flight track. The model captures less mixing between the vortex and midlatitudes by April, as the chemical loss in the lower latitude airmass has much less contribution from high latitudes and polar processes compared to the lower latitude airmass encountered on the 5 June 2000. 
Acknowledgements. The authors thank NERC for their support of the Egrett campaign and of the subsequent analysis of the measurements. D. Ross has been the recipient of a NERC studentship, and the campaign activities were supported through the Aircraft Measurements of Atmospheric Tracers in the UTLS project of the NERC UTLS OZONE programme. J. Pyle is supported in part by NCAS. N. Harris thanks the European Commission Research DG for support through the CRUSOE-II concerted action (EVK2-CT-2001-20012). We thank J. Whiteway, G. Vaughan and their groups at University of Wales at Aberystwyth, and the pilots, crew and all the personnel of the ARA Egrett and Boscombe Down for their efforts during the campaign. We thank J. Elkins and E. Richard (NOAA) for the use of the CFC- 11 and $\mathrm{O}_{3}$ measurements from the NASA ER-2. Finally we thank the anonymous reviewer, J.-U. Grooß and R. Müller for their constructive comments.

Edited by: W. Sturges

\section{References}

Appenzeller, C., Weiss, A. K., and Staehelin, J.: North Atlantic Oscillation modulates total ozone winter trends, Geophys. Res. Lett., 27, 1131-1134, 2000.

Bradshaw, N. G., Vaughan, G., Busen, R., Garcelon, S., Jones, R., Gardiner, T., and Hacker, J.: Tracer filamentation generated by small-scale Rossby wave breaking in the lower stratosphere, J. Geophys. Res., 107, 4689, doi:10.1029/2002JD002086, 2002.

Carslaw K. S., Kettleborough, J. A., Northway, M. J., Davies, S., Gao, R.-S., Fahey, D. W., Baumgardner, D. G., Chipperfield, M. P., and Kleinböhl, A.: A vortex-scale simulation of the growth and sedimentation of large nitric acid hydrate particles, J. Geophys. Res., 107, 8300, doi:10.1029/2001JD000467, 2002.

Chipperfield, M. P.: Multi-annual simulations with a threedimensional chemical transport model, J. Geophys. Res., 104, 1781-1805, 1999.

Fahey, D., Kawa, S. R., Woodbridge, E. L., Tin, P., Wilson, J. C., Jonsson, H. H., Dye, J. E., Baumgardner, D., Borrmann, S., Toohey, D. W., Avallone, L. M., Proffitt, M. H., Margitan, J., Loewenstein, M., Podolske, J. R., Salawitch, R. J., Wofsy, S. C., Ko, M. K. W., Anderson, D. E., Schoeberl, M. R., and Chan, K. R.: In situ measurements constraining the role of sulphate aerosols in mid-latitude ozone depletion, Nature, 363, 509-514, 1993.

Fahey, D. W., Gao, R. S., Carslaw, K. S., Kettleborough, J., Popp, P. J., Northway, M. J., Holecek, J. C., Ciciora, S. C., McLaughlin, R. J., Thompson, T. L., Winkler, R. H., Baumgardner, D. G., Gandrud, B., Wennberg, P. O., Dhaniyala, S., McKinney, K., Peter, T., Salawitch, R. J., Bui, T. P., Elkins, J. W., Webster, C. R., Atlas, E. L., Jost, H., Wilson, J. C., Herman, R. L., Kleinbohl, A., and von Konig, M.: The detection of large $\mathrm{HNO}_{3}$-containing particles in the winter Arctic stratosphere, Science, 291, 10261031, 2001.

Godin, S., Marchand, M., Hauchecorne, A., and Lefèvre, F.: Influence of Arctic polar ozone depletion on lower stratospheric ozone amounts at Haute-Provence Observatory $\left(43.92^{\circ} \mathrm{N}, 5.71^{\circ} \mathrm{E}\right)$, J. Geophys. Res., 107, 8272, doi:10.1029/2001JD000516, 2002.

Grooß, J.-U., Günther, G., Konopka, P., Müller, R., McKenna, D. S., Stroh, F., Vogel, B., Engel., A., Müller, M., Hoppel, K., Bevilac- qua, R., Richard, E., Webster, C. R., Elkins, J. W., Hurst, D. F., Romashkin, P. A., and Baumgardner, D. G.: Simulation of Ozone Depletion in Spring 2000 with the Chemical Lagrangian Model of the Stratosphere (CLaMS), J. Geophys. Res., 107, 8295, doi:10.1029/2001JD000456, 2002.

Hadjinicolaou, P., Pyle, J. A., Chipperfield, M. P., and Kettleborough, J. A.: Effect of Interannual Meteorological Variability on Mid-latitude $\mathrm{O}_{3}$, Geophys. Res. Lett., 24, 2993-2996, 1997.

Hauchecorne, A., Godin, S., Marchand, M., Heese, B., and Souprayen, C.: Quantification of the transport of chemical constituents from the polar vortex to middle latitudes in the lower stratosphere using the high-resolution advection model MIMOSA and effective diffusivity, J. Geophys. Res., 107, 8289, doi: 10.1029/2001JD000491, 2002.

Haynes, P. H. and Shuckburgh, E. F.: Effective Diffusivity as a Diagnostic of Atmospheric Transport Part 1 - Stratosphere, J. Geophys. Res., 105, 22 777-22 794, 2000.

Konopka, P., Grooß, J.-U., Bausch, S., Müller, R., McKenna, D. S., Morgenstern, O., and Orsolini, Y: Dynamics and chemistry of vortex remnants in late Arctic spring 1997 and 2000: Simulations with the Chemical Lagrangian Model of the Stratosphere (CLaMS), Atmos. Chem. Phys., 3, 839-849, 2003, SRef-ID: 1680-7324/acp/2003-3-839.

Lee, A. M., Roscoe, H. K., Jones, A. E., Haynes, P. H., Shuckburgh, E. F., Morrey, M. J., and Pumphrey, H. C.: The impact of the mixing properties within the Antarctic stratospheric vortex on ozone loss in spring, J. Geophys. Res., 106, 3203-3212, 2001.

Logan, J. A., Megretskaia, I. A., Miller, A. J., Tiao, G. C., Choi, D., Zhang, L., Stolarski, R. S., Labow, G. J., Hollandsworth, S. M., Bodeker, G. E., Claude, H., DeMuer, D., Kerr, J. B., Tarasick, D. W., Oltmans, S. J., Johnson, B., Schmidlin, F., Staehelin, J., Viatte, P., and Uchino, O.: Trends in the vertical distribution of ozone: a comparison of two analyses of ozonesonde data, J. Geophys. Res., 104, 26 373-26399, 1999.

Manney, G. L. and Sabutis, J. L.: Development of the Polar Vortex in the 1999-2000 Arctic Winter Stratosphere, Geophys. Res. Lett., 27, 2589-2592, 2000.

Marchand, M., Godin, S., Hauchecorne, A., Lefèvre, F., Bekki, S., and Chipperfield, M.: Influence of polar ozone loss on northern midlatitude regions estimated by a high-resolution chemistry transport model during winter 1999/2000, J. Geophys. Res., 108, 8326, doi:10.1029/2001JD000906, 2003.

Millard, G. A.: Numerical Modelling of Polar and Middle Latitude Ozone Loss, PhD Thesis, University of Cambridge, 2002.

Millard, G. A., Lee, A. M., and Pyle, J. A.: A model study of the connection between polar and midlatitude ozone loss in the Northern Hemisphere lower stratosphere, J. Geophys. Res., 107, 8323, doi:10.1029/2001JD000899, 2002, [printed 108 (D5), 2003].

Müller, R., Tilmes, S., Grooß, J.-U., McKenna, D. S., Müller, M., Schmidt, U., Toon, G. C., Stachnik, R. A., Margitan, J. J., Elkins, J. W., Arvelius, J., and Russell III, J. M.: Chlorine activation and chemical ozone loss deduced from HALOE and balloon measurements in the Arctic during the winter of 1999-2000, J. Geophys. Res., 107, 8302, doi:10.1029/2001JD001423, 2002, [printed 108 (D5), 2003].

Newman, P. A., Harris, N. R. P., Adriani, A., Amanatidis, G. T., Anderson, J. G., Braathen, G. O., Brune, W. H., Carslaw, K. S., Craig, M. S., DeCola, P. L., Guirlet, M., Hipskind, R. S., 
Kurylo, M. J., Küllmann, H., Larsen, N., Mégie, G. J., Pommereau, J,-P., Poole, L. R., Schoeberl, M. R., Stroh, F., Toon, O. B., Trepte, C. R., and Van Roozendael, M.: An Overview of the SOLVE-THESEO 2000 Campaign, J. Geophys. Res., 107, 10.1029/2001JD001303, 2002.

Peters, D. and Waugh, D. W.: Influence of barotropic shear on the poleward advection of upper tropospheric air, J. Atmos. Sci., 53, 3013-3031, 1996.

Piani, C., Norton, W. A., Iwi, A. M., Ray, E. A., and Elkins, J. W.: Transport of ozone-depleted air on the breakup of the stratospheric polar vortex in spring/summer 2000, J. Geophys. Res., 107, 8270, doi:10.1029/2001JD000488, 2002.

Plumb, R. A., Waugh, D. W., and Chipperfield, M. P.: The effects of mixing on tracer relationships in the polar vortices, J. Geophys. Res., 105, 10 047-10 062, 2000.

Prather, M. J.: Numerical advection by conservation of secondorder moments, J. Geophys. Res., 104, 6671-6681, 1986.

Proffitt, M. H., Margitan, J. J., Kelly, K. K., Lowenstein, M., Podolske, J. R. and Chan, K.: Ozone loss in the Arctic polar vortex inferred from high-altitude aircraft measurements, Nature, 347, 31-36, 1990.

Pyle, J. A., Chipperfield, M. P., Kilbane-Dawe, I., Lee, A. M., Stimpfle, R. M., Kohn, D., Renger, W., and Waters, J. W.: Early Modelling Results from the SESAME and ASHOE Campaigns, Faraday Discussions, 100, 371-387, 1995.

Rex, M., Salawitch, R. J., Harris, N. R. P., von der Gathen, P., Braathen, G. O., Schulz, A., Deckelmann, H., Chipperfield, M., Sinnhuber, B.-M., Reimer, E., Alfier, R., Bevilacqua, R., Hoppel, K., Fromm, M., Lumpe, J., Küllmann, H., Kleinböhl, A., Bremer, H., von König, M., Künzi, K., Toohey, D., Vömel, H., Richard, E., Aikin, K., Jost, H., Greenblatt, J. B., Loewenstein, M., Podolske, J. R., Webster, C. R., Flesch, G. J., Scott, D. C., Herman, R. L., Elkins, J. W., Ray, E. A., Moore, F. L., Hurst, D. F., Romashkin, P., Toon, G. C., Sen, B., Margitan, J. J., Wennberg, P., Neuber, R., Allart, M., Bojkov, B. R., Claude, H., Davies, J., Davies, W., De Backer, H., Dier, H., Dorokhov, V., Fast, H., Kondo, Y., Kyrö, E., Litynska, Z., Mikkelsen, I. S., Molyneux, M. J., Moran, E., Nagai, T., Nakane, H., Parrondo, C., Ravegnani, F., Skrivankova, P., Viatte, P., and Yushkov, V.: Chemical Depletion of Arctic Ozone in Winter 1999/2000, J. Geophys. Res., 107, 8276, doi: 10.1029/2001JD000533, 2002.
Rex, M., Harris, N. R. P., von der Gathen, P., Lehmann, R., Braathen, G. O., Reimer, E., Beck, A., Chipperfield, M. P., Alfier, R., Allaart, M., O'Connor, F., Dier, H., Dorokhov, V., Fast, H., Gil, M., Kyro, E., Litynska, Z., Mikkelsen, I. S., Molyneux, M. G., Nakane, H., Notholt, J., Rummukainen, M., Viatte, P., and Wenger, J.: Prolonged Stratospheric Ozone Loss in the 1995-96 Arctic Winter, Nature, 389: 835-838, 1997.

Richard, E. C., Aikin, K., Andrews, A. E., Daube, B. C., Gerbig, C., Wofsy, S. C., Romanshkin, P. A., Hurst, D. F., Ray, E. A., Moore, F. L., Elkins, J. W., Deshler, T., and Toon, G. C.: Severe chemical ozone loss inside the Arctic polar vortex during winter 19992000 inferred from in situ airborne measurements, Geophys. Res. Lett., 28, 2197-2200, 2001.

Robinson, A. D., McIntyre, J., Harris, N. R. P., Pyle, J. A., Simmonds, P. G., and Danis, F.: A Lightweight Balloon-Borne Gas Chromatograph for in-Situ Measurements of Atmospheric Halocarbons, Rev. Sci. Instru., 71, 4553-4560, 2000.

Shine, K. P.: The middle atmosphere in the absence of dynamical heat fluxes, Q. J. R. Meteorol. Soc., 113, 603-633, 1987.

Sinnhuber, B. M., Chipperfield, M. P., Davies, S., Burrows, J. P., Eichmann, K. U., Weber, M., von der Gathen, P., Guirlet, M., Cahill, G. A., Lee, A. M., and Pyle, J. A.: Large loss of total ozone during the Arctic winter of 1999/2000, Geophys. Res. Lett., 27, 3473-3476, 2000.

Solomon, S., Portmann, R. W., Garcia, R. R., Thomason, L. W., Poole, L. R., and McCormick, M. P.: The role of aerosol variations in anthropogenic ozone depletion at northern midlatitudes, J. Geophys. Res., 101, 6713-6727, 1996.

Waugh, D. W. and Rong, P.-P.: Interannual Variability in the Decay of Lower Stratospheric Arctic Vortices, J. Meteor. Soc. Japan, 80, 997-1012, 2002.

Weiss, A. K., Staehelin, J., Appenzeller, C., and Harris, N. R. P.: Chemical and Dynamical Contributions to Ozone Profile Trends of the Payerne (Switzerland) Balloon Soundings, J. Geophys. Res., 106, 22 685-22 694, 2001.

World Meteorological Organisation, Scientific Assessment of Ozone Depletion: 2002, WMO Global Ozone Research and Monitoring Project - Report No. 47, 498, Geneva, 2003. 